Article

\title{
Performing, Representing, and Archiving Belief: Religious Expressions among Jazz Musicians
}

\author{
Vaughn A. Booker \\ Department of Religion, Princeton University, 1879 Hall, Princeton, NJ 08544, USA; vbooker@princeton.edu \\ Academic Editors: Douglas James Davies and Michael J. Thate \\ Received: 30 March 2016; Accepted: 12 August 2016; Published: 19 August 2016
}

\begin{abstract}
The archives of African American jazz musicians demonstrate rich sites for studying expressions of religious belief and daily religious practice in public and private arenas, in professional and personal capacities. Highlighting print material from the archives of Edward Kennedy "Duke" Ellington (1899-1974) and Mary Lou Williams (1910-1981), this article examines the ways that these musicians worked to articulate their beliefs in print and to make meaning of their routine practices. Ellington and Williams produced written records of their aspirations for non-clerical religious authority and leadership, novel notions of religious community, and conceptions of quotidian writing tasks as practices with devotional value in the middle decades of the twentieth century. In preparation for his Sacred Concert tours of American and Western European religious congregations, Ellington theologized about the nature of God and the proper language to address God through private hotel stationery. Following her conversion to Roman Catholicism, Williams managed a Harlem thrift shop and worked to create the Bel Canto Foundation for musicians struggling with substance abuse and unemployment. This study of the religious subjectivity of African Americans with status as race representatives employs archival historical methods in the effort to vividly approximate complex religious interiority.
\end{abstract}

Keywords: African American religious history; Religion in America; jazz; Duke Ellington; Mary Lou Williams

\section{Introduction: Records of Religious Rigor}

This article focuses on two African American pianists and composers in the jazz tradition, Edward Kennedy "Duke" Ellington and Mary Lou Williams, who fashioned public personae as race representatives and who had significant religious statements to say-or express-in the late 1950s and 1960s. These musicians operated within a jazz profession that underwent a decades-long transition in social perception from its association with a vicious urban nightlife that corrupted black youth to its treatment as a virtuosic art form conducive to progressive race representation [1]. Key to these famous musicians' self-awareness as race representatives is the preservation of their documents in national and university archives, with Ellington's materials at the Smithsonian and Williams's records at Rutgers University's Institute of Jazz Studies [2]. Both Ellington and Williams produced sacred jazz music through album recordings and religious concerts, and their archives often reflected the detailed thought processes and business organization to manage and produce these professional endeavors. This article locates religious practice and the articulation of belief in these musicians' archives.

This work originates from a broader project that explores religious practice at the intersection of public racial identity (race representation) and personal articulations of religious identity (expressions 
of belief) in twentieth-century African American religious history. ${ }^{1}$ The contemplative private practices of Ellington and Williams shaped and refined the linguistic and performative choices these individuals made to present their religious identities to various publics. However, the presentation of such choices became public via historical bodies situated within cultural and national contexts and affiliations. Raced, gendered, classed, and aged religious subjects employ choices of language and expression in their presentations of self, and these choices also inherently constitute representations of other subjects with whom they claim association or with whom other publics identify them. For African Americans in the mid-twentieth century, public religious expression always entailed race representation [3].

Duke Ellington's archive of undated hotel stationery expressed his belief in God, his frustrations with language to refer to God, and his appeal to the very act of believing. This hotel stationery, in conversation with his religious literature and ministerial friends, serves as an unexamined arena of his personal religious exploration, reflection, and contention in the process of crafting music to make public expressions of belief. Ellington's ultimate aspiration was to use his preferred language of music to express wordlessly the proper reverence for God; in the process, however, he wrote lyrics attempting to accurately convey his assessment that existing language was inadequate to capture what it meant to believe in and to speak of God. Ultimately, the concepts of God and of love became synonymous for Ellington, articulated most vocally in his final Sacred Concert. The primary context for examining Ellington's expressions of belief and conceptions of God is the composition of specific songs for performance in his Three Sacred Concerts, premiering in 1965, 1968, and 1973-which also served to revitalize Ellington's career as he entered his seventies.

Additionally, my study of Mary Lou Williams through her Bel Canto Foundation archive articulates personal and communal meaning in what appeared to be her professional failure. To render Williams's rigorous daily activity visible through an exploration of her business archive is to contest the portrait of her work from 1958 to about 1966 as insufficient, amateurish folly and an eccentric preoccupation which distracted Williams from her more laudable musical pursuits. Williams's daily labor was a manifestation of her personal conception of a divine call, and with this material, I also reveal how Williams practiced and articulated her personal beliefs-making one African American/Catholic convert/jazzwoman's meticulous labor visible while also making her business records legible as a form of print culture which documented her religious work. Through an attempt to restructure a community of African American jazz artists and their supporters, Williams pursued charitable social work as the institutionalization of personal accountability. She attempted to institutionalize personal habits of supporting others in order to aid musicians who experienced many of the frustrations with their profession that she knew well. This was a translation of personal practices, prior to her Catholic conversion, into the language of charitable organizations, following her Catholic conversion, as recognized by the governmental bureaucracy. Such a charitable strategy was not unfamiliar to many Christian denominations in the United States, and in Williams's personal case, the production of "good sounds" was her ultimate goal for rehabilitated, creative African American jazz musicians.

1 With this larger project, I claim that black jazz musicians emerged as "race professionals" because of an African American middle-class Protestantism in the first half of the twentieth century that modeled religious and racial representations of African Americans as professional duties. The emergence of jazz presented a leisure culture that religious African American middle-class professional men and women decried, while black Protestant middle-class youth who enjoyed this culture emerged from it as the black jazz professionals and aficionados in the black press who shaped the music they loved into an art form they deemed an appropriate, alternative vehicle for race representation. Accompanying that race representation in (un)intentional forms were various expressions of prominent African American religious belief and practices in the early twentieth century, evident through three major themes: irreverent performances of African American religious leadership and expressive acts of worship; a sacralization of "Africa" in narratives of African American history; and with celebrated jazz musicians who committed to black Protestants' social and political activism against Jim Crow through the desegregation of performing venues, financial support of civil rights activism, and intentional crossover racial appeal. 


\section{2. "An Eligible light of Semantics that's Right for the One God Divine"}

Duke Ellington grew up in Washington, D.C.'s black middle class at the turn of the twentieth century, and his mother took him to at least two churches every Sunday (Nineteenth Street Baptist and John Wesley A. M. E. Zion, his father's family church) ([4], pp. 12-15). The young Ellington was educated in an environment that saw the staging of historical plays and pageants by civic groups, schools, and churches to instill race pride for Africa's descendants. Ellington the composer "musicalized" African American history, and the first two decades of his career saw conscious attempts to assert an appreciation for blackness in songs like "Black and Tan Fantasy" (1927), "Symphony in Black" (1934), "Black Butterfly" (1936), "Black Beauty" (1938), and in Black, Brown and Beige (1943), Ellington's extended symphonic "tone parallel to the history of the Negro in America" [5]. As he prepared his musical compositions for his first Sacred Concert in 1965, Ellington wrote in a rough copy of his program text, "In the beginning, we only existed in the mind of GOD, and so GOD, very graciously, shared with us a life of our own" [6]. These hotel stationery notes reveal that while traveling, Ellington made constant attempts to characterize God in his own language, and he debated the precise language others employed to capture the nature of God for his songs. In one private hotel moment, Ellington expressed a definition of God through personal experience with the natural world: "I Can Hear GOD Anytime/I Can Feel GOD in the Sun Rise/the Smell \& the Taste/of the Wind \& the Sea/MAKES ME See GOD When I Close My Eyes" [7]. At other times, Ellington turned to religious literature to encounter other conceptions of God within Christian traditions. Some of this literature he acquired from his fans and friends in positions of religious leadership, and he sustained an engagement with it in the process of composing his three Sacred Concerts.

Ellington read Destined for Greatness, a booklet by Life Messengers, "an evangelical non-profit organization" based in Seattle, Washington. Life Messengers was a publishing ministry founded in 1944 by Ray W. Johnson and his wife, Vera. Johnson, a graduate of the Moody Bible Institute, was also the publisher of The Last Days Bible, which focused on premillennial evangelical concepts of the impending apocalypse [8]. Destined for Greatness is an apologetic narrative tract, with "Dr. Fronkby" at the center of the encounter over proof of God's existence and the literal reliability of the Bible. Dr. Fronkby is a scientist who is convinced of God's existence and biblical infallibility, and he engages a group of students who challenge his rationale behind evangelical Christian commitment versus modern science's presumed opposition to it. Dr. Fronkby fielded students' various questions: John asked, "...[I]f there is a God and He created everything, who made God?" followed by "'But why didn't God reveal something about how He came to be?' John persisted. 'If He does exist why hasn't He explained His existence? Maybe I could believe if He would explain His own beginning'" [bold in original]. In his booklet, Ellington drew a question mark and circled it next to this passage. In response to Steve, who asked Dr. Fronkby, "But why is God so secretive about His beginnings?" Ellington wrote "HOW DARE WE" at the page bottom, and at the top of the next page he wrote "WE DON'T UNDERSTAND ALL THINGS ON EARTH-TANGIBLE." In his response to this series of questioning, Dr. Fronkby speaks of God's beginning, "What He has chosen not to reveal is none of our business." Here, Ellington bracketed this sentence and wrote "GOD" on top of "He," placing this sentence, which he considered a compelling response, in his preferred theological language ([9], pp. 12-14). Similarly, Susan's question to Dr. Fronkby about the concept of the Trinity and God permitting Jesus Christ's substitutionary atonement ("[W]hy didn't He show His great love for us by coming Himself instead of sending His Son to suffer? Why didn't He suffer for us instead?") irked Ellington, as evidenced by the addition of a question mark to the paragraph and the writing of "STUPID" after Susan's question ([9], p. 22).

Precise language to address directly (and speak about) God was a paramount concern for Ellington, as expressed in his hotel stationery. An Ellington stationery writing at the Hilton in Jacksonville, Florida adds texture to his expressed frustrations with the exchange between the fictional Dr. Fronkby and the students: 
What Made You Think^ (That) You Can Use the Word HIM

Why Do You Refer to the Almighty as HE

When You Pray ^ (First Person) How Dare You Address the LORD as YOU

Him, You \& He

Are Correct When Addressing Me [10].

Addressing an unspecified believing subject, Ellington adopted privately a tone of frustration with the commonplace usage of masculine pronouns and titles to refer to God. Ellington even attempted to craft lyrics for a tune, titled "There is No Pronoun Good Enough for GOD," which expressed his belief that regal addresses like "His or Her Majesty" and "Your Highness" for royals or "Your Honor" for a judge fall short of adequacy when speaking to the divine [11]. A Washington, D.C. reflection expressed his lament over the absence of sufficiently exclusive language: "With So Many ^ (Educated[,] Brilliant) People (Scholars) With Such Highly Developed Vocabularies-In So Many, Many ^(Sophisticated) Languages \& Not One, Who Think[?] of a Worthy Pronoun." When referring to God, the archaic "thou" and capitalized masculine pronouns were apparently insufficient for Ellington. And he ended this note by declaring, "GOD is Beyond Gender" [12].

To consider the supreme deity "Beyond Gender" was, at base, a clear statement relegating gendered language to the created, material world. However, this particular phrasing is likely significant in Ellington's language, given his history of considering others "beyond" standard classification. For other artists, to be "Beyond Category" in the jazz world was to bear Ellington's highest praise. Fellow musicians Mary Lou Williams and Ella Fitzgerald received this veneration, with the latter artist receiving a musical tribute when Ellington and Billy Strayhorn composed "Portrait of Ella Fitzgerald" with a third movement titled, "Beyond Category." It is likely, therefore, that this assertion of a genderless deity is simultaneously Ellington's assertion of God's superiority to gendered descriptions and an expression of high religious praise.

The evidence of this descriptive theological assertiveness would not appear as a direct message in any of the songs from Ellington's three Sacred Concerts. However, Ellington created a symphonic composition, titled "New World A-Comin'," inspired by Roi Ottley's Peabody award-winning 1943 book on African American society, New World A-Coming: Inside Black America. Ellington's "New World A-Comin'," with the composer's spoken-word introduction in the 1970 orchestral album recording, envisioned a future where "there will be no war, no greed, no categorization, no nonbelievers, where love is unconditional, and there is no pronoun good enough for God" [13]. Ellington included his solo piano performance of "New World A-Comin"” in his First Sacred Concert tour.

The composer pursued the use of terminology to address and describe God that could not apply to any other subject or concept. This must have been a constant thought process for Ellington while traveling, for his poetic reflection in San Antonio, Texas describes his pursuit of such elusive language:

My Dear GOD I've Been Searching

Searching For the Word or the Phrase

that Cannot Be Use[d] [for?] any Purpose

\& Has Not Been Used Through All the Universal Days

My Dear GOD I've Been looking,

Listening, looking \& Trying to Find

An Eligible light of Semantics

that's Right For the One God Divine

When Speaking to or Of My Dear GOD

There's Not One Pronoun

that Hasn't Been Used for Others

\& Not One That Hasn't Been Used I've Found No Not One I've Found [14]. 
With music, Ellington was able to find or create a particular phrase, theme, or melody to express a particular concept, mood, person, or group of people. However, he appeared unsatisfied with an inability to do likewise with existing language about the divine. Additional hotel stationery reflections in Greensboro, North Carolina and Baltimore, Maryland indicate that Ellington momentarily considered the exclusive use of the first person pronoun by God-and God alone-acceptable. He declared "The Only Pronoun Good Enough for God is 'I' When used in the FIRST PERSON" at one moment, and he also wrote, "There is only "(the) ONE Pronoun/good Enough For GOD/\& It Can

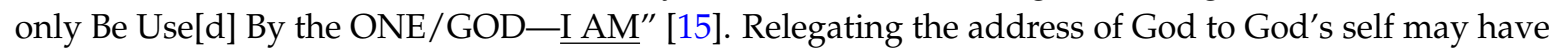
served to convey the essential ineffability Ellington felt in his reverence for the divine. The practice of generating such written statements about God may have even served as acts of private worship for Ellington. However, this work would not suffice for Ellington's attempt to capture the worshipful rhetoric of believers in the God of the Hebrew Bible for the songs he was composing. The Baltimore reflection in which Ellington refers to God as "the ONE" reveals an attempt to employ a numerical pronoun to address the Almighty, and a reflection in Honolulu, Hawaii reveals Ellington's seemingly meditative attempts to spell out this form of reverence through repetition of the title "the One" [16].

Ellington had used "the One" to refer to God in a composition predating his three Sacred Concerts. In 1963, he composed a stage play, My People, what he deemed a "social significance" work intended for a children's audience during the height of the Civil Rights Movement-reminiscent of the pageants from Ellington's childhood like W. E. B. Du Bois's The Star of Ethiopia. This play was broadcast so that black children, the larger white American viewership, and a wider European audience would know that "there are Negro doctors, lawyers, businessmen, nurses, teachers, telephone operators, policemen, and housewives," and that they are worthy of admiration ([17], pp. 393, 395). One of the particularly religious compositions for this broadcast was titled, "Ain't But the One," performed by Ellington's orchestra and featuring the lead vocals of Jimmy McPhail and the backing vocals of the Irving Bunton Singers. Employing the familiar "call and response" singing method of black gospel music, "Ain't But The One" reflected Ellington's strident monotheism through a recording of God's activity as chronicled primarily in the Hebrew Bible, invoking events that would have been familiar to any African Americans attached to the tradition of music derived from African American spirituals. But the lyrics for "Ain't But the One" made use of implied pronouns (and interrogative pronouns) when describing God, effectively serving Ellington's linguistic contention by evading their usage altogether. McPhail and the Irving Bunton Singers alternated choruses of "Ain't but the One (just One)" when describing the "one good Lord above" or the "one great God of love." McPhail spoke of a God who "made a serpent wiggle from a walking stick/made a snake out of a cane," and he asked "who set the stars (sun and the moon)?" and "who knows the judgment (just who)?" without the use of "He" [18]. Ellington later incorporated "Ain't But the One" into his first Sacred Concert, thereby conveying to religious audiences nationwide his appraisal of the African American Christian musical tradition while subtly omitting the use of the masculine pronoun most Christians associated with God. ${ }^{2}$

2 For the televised We Love You Madly Tribute to an ailing Duke Ellington in 1973, Ray Charles and Aretha Franklin re-imagined Ellington's "Ain't But the One" by setting his lyrics to the basic structure of their song, "Spirit in the Dark." The song includes not only an organ, electric guitar, and a mass gospel choir behind Charles and Franklin, intimately familiar with the idioms of modern gospel music, but it also contains a "praise break" showcasing these two musicians' improvisational spirit. In a sense, this reworking of the song affirms the theological content of Ellington's lyrics as sufficiently representative of African American Christianity. However, the Franklin and Charles version uses the pronoun "He" when referring to God. Coupled with their musical arrangement, which supplants Ellington's as a more authentic representation of modern gospel music that is conducive to Pentecostal worship practices, Charles and Franklin translate Ellington's message into the words and sounds most familiar to the black Christian communities with which they were well acquainted. These changes also simply signal generational and religious differences between musicians-Ellington had not been a church-attending religious person, and his Washington, DC black Baptist and Methodist upbringing in the black middle class bore mainly the strong influence of African American spirituals, not gospel music. 
Besides use of "the One," Ellington composed "Supreme Being" for his Second Sacred Concert, an epic song similar to the first Sacred Concert's "In the Beginning, God" in its focus on the Hebrew Bible's Genesis creation narrative, but relying primarily on the choir and soloists' spoken word following an arranged instrumental opening:

\author{
Supreme Being! \\ Supreme Being \\ There is a Supreme Being \\ There is one, only one, one Supreme Being \\ Out of lightning, thunder, chaos and confusion \\ The Supreme Being organized and created \\ Created and organized heaven and earth \\ $[\ldots]$ \\ Supreme Being. \\ The immortal creator and ruler of the universe, eternal and all-powerful \\ Supreme Being \\ Called God! [19].
}

To speak repeatedly of one "Supreme Being" allowed Ellington to marshal many familiar religious descriptors for this divine concept, contemplating this being and its attributes for over four minutes, before the chorus reveals (by building to an exclamation) that it is also "called God!" But this prose also allowed Ellington to signify that the capitalized word "God" that many English-speaking monotheists use to refer to this "Supreme Being" inevitably fell short of fully capturing the divine object of reverence. In this instance, more words rather than fewer were necessary for Ellington to represent to the listener the particular, epic biography of this entity of utmost existence.

Why wasn't "Jesus" a sufficient noun? Language about Jehovah, Yahweh, the Holy Ghost (or Spirit) is absent from Ellington's hotel stationery reflections. Similarly, Jesus's name appears once in this collection. ${ }^{3}$ According to Ellington biographer Harvey Cohen, a 1958 interview revealed that Ellington regularly wore a gold cross under his shirt but also that he "almost never spoke about Jesus Christ directly, either in conversation or in the lyrics for his sacred compositions" ([17], p. 448). In Ellington's first Sacred Concert, the gospel singer Esther Marrow stated in "The Lord's Prayer" that she was "beggin you, Jesus, to give me more grace/I need your power to help me to run this race" before improvising on the New Testament "Our Father" / model prayer. It is possible that Ellington granted Marrow the improvisational freedom to use her preferred divine language; nevertheless, the almost total absence of the name Jesus or the title Christ from Ellington's compositions is significant. Two exceptions are possible allusions to Jesus in "Ain't But the One" and "Tell Me It's the Truth." In "Ain't But the One," Jimmy McPhail's line "Made the cripple walk and the blind man see" refers to two acts of Jesus that the New Testament gospels provide, although this lyrical presentation also allows for attribution of the healings to the power of God. "Tell Me It's the Truth" references "the Gospel truth," because "the truth is the light and the light is right"—and to Marrow's "right?" Ellington answered, "right" [20]. However, Marrow appears to sing "Tell me it's $a$ truth" in the Grace Cathedral premiere and on the album version, despite the album version's song title and versions by other Sacred Concert singers since. ${ }^{4}$ Through the song, the singer appears in need of assurance that something is

3 One undated piece of hotel stationery (without a location) reveals Ellington similarly thought about how to properly address Jesus Christ as God's son: "People Who Have the Honor to Be Presented to a prince or Princess—-[the] Son or Daughter-of a King is addressed ^(or referred to) as your ^ (or His) Highness-Not He or She/But Not Jesus Christ-\& Jesus is the Son of GOD/Why is Proper Protocol ^ NOT Provided [to?] the Son of GOD-Jesus Christ—" Although Ellington's desire for exclusive language to appropriately address the "Son of GOD" may reveal a significant place for Jesus in Ellington's theology, it does not indicate conclusively that he held God and Jesus (alongside the Holy Spirit) as equal deities, or that the "Son of GOD" was also "God the Son."

4 This appears to also be the case for Duke Ellington's recorded concert at Fountain Street Church in Grand Rapids, Michigan on 17 April 1966. 
either true or "the truth," and the allusion to Jesus as either the biblical "truth" or "light" is possible but unclear with this song. In both cases, Ellington elected to avoid direct mentions of Jesus or Christ.

A rhyming reflection that Ellington wrote on hotel stationery in Houston, Texas serves as his attempt at a proverb, imitating a Shakespearean line from The Merchant of Venice: "It's a Wise Man Who Knows His Father/It's a Wise Man Who Knows His Son/It's a Wise Man Who Knows that GOD/\& that GOD is the One and Only One" [21]. A Christianity Today profile of Ellington possibly shed light on these theological absences:

His Washington, D.C. boyhood was filled with sermons and Sunday school, but Ellington has rarely attended services during his career and never joined a church. At 23, with a jazz career beginning to bloom, "I began to read the Bible for myself, to see what there was. I have my own idea, and I think it makes sense." This idea strays from the orthodox belief on the Trinity, but he is conservative about the Bible itself. "I believe the whole story," he said. "I am always in a position to have it out with people who say the Bible contradicts itself. I'm not a formal Bible student, but I can correct people on things like that." [22].

While the profile offered no specific stances Ellington many have had regarding the idea of God existing simultaneously in three persons, it conveyed the musician's confidence in his own ability to comprehend, interpret, and defend Hebrew and Christian scriptures without conventional clerical guidance. The article glossed the prospect of Ellington's unitarian personal theology (perhaps this explains his frustration with the fictional student questioning Dr. Fronkby about God suffering in Jesus's crucifixion?) in order to focus on his affirmation of the existence of God. Christianity Today's mission was to promote a more conservative evangelical Christian voice in print magazine culture than the mainline Protestant magazine, The Christian Century.

Ellington's sacred music represented an attempt to craft new religious sounds, and his presence in various churches and synagogues indicated the prospect of interracial fellowship and the creativity it was able to produce if more Americans committed to integration and welcomed African Americans into their religious spaces. His Sacred Concerts proclaimed belief, albeit a general belief in a supreme deity, and the defense of believing was sufficient for those religious participants like Ellington who elected to operate within an interfaith world. However, the lyrics of his compositions never expressed the particular belief in Jesus's resurrection, atonement, or divinity.

As a public representative of receptivity to religious belief, Ellington became a repository or vessel for other religious leaders' more pronounced and firm religious commitments, and they sent him religious materials as gifts in order to persuade him to join their religious communities. For Ellington to express divine belief without adhering to any particular Christian denomination meant that others were willing to send him scriptures and religious literature to compel him in particular theological directions. Ellington's apparent openness left him vulnerable to accusations by his critics of insincere piety and superficial belief. But such openness also made him likely to forge new religious relationships that became friendly correspondences, some of which fed into the Sacred Concerts. Ellington's collection of religious literature reveals that a profession of religious commitment in twentieth-century America did not seal the individual off from the reality of competing religious commitments, which may even have appeared as the well-intentioned proselytizing of others who admired the popular jazz musician and sought to welcome him into their particular fellowships. Nevertheless, Ellington received these gifts as clergy encouraging him to create sacred music "not as a matter of career, but in response to a growing understanding of my own vocation" [23]. In general, for Ellington to proclaim divine ineffability in public songs and private writings was both a product and practice of his personal religious wrestling, contemplation, and devotion.

Endowed with the trust of many ministers and religious institutions to present a statement of faith, Ellington made use of these public settings to serve as an African American representative of religious fidelity who was privately in the constant process of working out the nature of that belief. Although granted a unique opportunity, Ellington's wrestling reflects the individual lives of many religious 
adherents and troubles the assumption that an individual's commitment to religious institutions, assent to doctrinal statements, or participation in religious rituals implies a shared, uncomplicated understanding of those spaces, languages, actions, or objects of reverence. The following section on Mary Lou Williams explores another jazz musician's sense of personal religious calling that resulted in her diligent, detailed, daily work to forge a position of unconventional religious leadership and race representation.

\section{Personal Mission, Professional Accountability}

Mary Lou Williams was born with a "veil" and had visions as a child, and she likely had a family of religious people around her who encouraged a notion of her wielding spiritual gifts. But Williams did not explore "conventional" religious traditions until after the death of jazz saxophonist and composer Charlie Parker from years of hard substance abuse. Williams engaged in prayer and "ascetic" practices like fasting and abstaining from purchasing luxuries. This followed an intense period of continued visions and accompanied close friendships with jazz trumpeter John Birks "Dizzy" Gillespie and his wife Lorraine, a Catholic convert. Lorraine encouraged Williams's exploration of Catholicism, while Gillespie encouraged her to return to performing music. She viewed her music, and the music industry itself, as antithetical to her religious mission before meeting a black Catholic friar, Mario Hancock, who encouraged her to compose religious reflections as part of her calling.

The 1960s and 1970s saw Williams composing many religious works. The Roman Catholic reforms of Vatican II afforded her a vehicle to promote the concept of "sacred jazz" by providing music "for the disturbed soul." Her music for Catholic liturgy contained gospel influences, and Williams, as a champion of jazz education, sought to make clear to others the roots of authentic American music in spirituals and the blues. Black Christ of the Andes celebrated the seventeenth-century Afro-Peruvian Catholic Saint Martin de Porres, "Dirge Blues" was a memorial to President Kennedy (the first Catholic U.S. president), and concerts like Praise the Lord in Many Voices, Mass for Lenten Season, and Mass for Peace saw Williams and her music circulating throughout Catholic churches in an attempt to get a male-dominated and formerly segregated religious institution to take seriously her musical talents, religious sincerity, and the general presence of black Catholics. In the early 1970s, Williams articulated the sacred origins of jazz through a particular African American heritage:

Through our suffering God took pity on us and created the world's greatest true art: the "Negro Spirituals" and from the Spirituals: Jazz was born in all its creative and progressive forms...Jazz is also a healer of the mind and soul. God reaches others through it to bring peace and happiness to those who know how to listen to it. [24]

Williams reiterated her belief about jazz music's divine origins in a 1978 interview, adding the notion that performing and listening to the music had spiritually therapeutic benefits: "God did blacks a favor by creating jazz especially for them. God helps people through jazz; people have been healed through it. It has happened to me" ([25], p. 36).

Williams articulated her new religious calling following the death Charlie Parker, her friend whose musical creativity in forging "bebop" (along with trumpeter Dizzy Gillespie and pianist Earl Rudolph "Bud" Powell) she encouraged. Having returned to the United States from Europe in 1954, and familiar with Parker's heroin addiction, Williams received word in 1955 about Parker's declining state from her brother, Jerry, who spotted him leaving Harlem Hospital. Since she often cared for musicians in her Hamilton Terrace apartment, Williams relayed to Parker through Jerry that he should "come by the house" ([26], p. 144; [27], p. 67). Unfortunately, Parker died a few days later. According to Williams biographer Tammy Kernodle, this loss made her despondent about the state of the jazz community and its music, given its demonstrated inability to provide care and safety nets for others:

[Charlie Parker's] death symbolized for Mary everything she thought had gone wrong with the jazz scene and the larger black community. Personal accountability and responsibility to the community had been replaced by an attitude focused on the individual and on 
personal advancement. Apparently no one had considered intervening with Parker; those around him simply distanced themselves when his behavior became too much to bear. Some fed his chemical demons in order to anesthetize or control him. ([28], pp. 167-77)

Unrealized creativity for jazz musicians, and the material insecurities it produced, became Williams's chief concerns, which she sought to remedy through religious care. Following Charlie Parker's death, Williams served as a co-chairperson of the Charlie Parker Foundation, established to support the late musician's children. A memorial concert for Parker, featuring Williams, Gillespie, and others, raised $\$ 10,000$. This success inspired in Williams a desire to establish an organization for struggling musicians and children, which she named the Bel Canto Foundation ([28], p. 177, and [29], p. 245).

To raise funds for the foundation, Williams opened a thrift shop to sell second-hand goods (including luxury items) to New York City's low-income patrons. As she reflected, the thrift shop came to occupy a place in Williams's daily routine, at first alongside nursing musicians in her home and attending Catholic worship services:

I'd meet the musicians and like if anybody was hung up I'd take them into church and I'd teach them to pray, how to do the rosary beads. I used to sit in the Lady of Lourdes. I'd go to the mass in the morning, 7 o'clock mass, and sit through all the masses. I'd get out about 9 or 10. I'd come home and fix lunch for all the poor people I had in the house I was feeding. I'd go right back and meditate a couple hours and then I'd come home. I was from the house to the store to the church. ([26], p. 156)

Eventually, Williams ceased housing musicians in her apartment to focus her efforts more fully on fundraising for her foundation and managing the store (although she continued to provide their convalescence elsewhere) ([26], p. 160; [27], pp. 78-80). ${ }^{5}$ In part, this Bel Canto Foundation story illuminates an African American woman managing a business, attentive to her income and influence. But the Bel Canto Foundation story has also been about failure, born of Williams's insufficient income and experience. Criticisms of Williams's efforts to establish the Bel Canto Foundation regarded the thrift shop she managed as "more a place to socialize than to do business." Williams biographer Linda Dahl even quoted the jazz musician's friend and later manager, Father Peter O'Brien, who stated, "She was not tough enough to run a business" ([29], p. 294). Dahl characterizes her donation standards and practices as unfeasible and unwise: "All an applicant had to do was give his name and address to receive a small check from Mary. This of course could not, and did not, last long" ([29], p. 265). Ultimately, this critical voice stemmed from the negative reflections of Williams's friends and fellow jazz musicians, who watched Williams care for other musicians with extreme devotion but found her religious exhortations off-putting ([29], p. 255). The value of revisiting Williams's Bel Canto Foundation archive is to reassess her management, fundraising, and store operation as daily religious labor that ensured her care-and creation of community—for many struggling jazz musicians.

With the legal assistance of Herbert Bliss, Williams incorporated the Bel Canto Foundation ([28], p. 190). The Bel Canto Foundation, Inc.'s charter stated the following primary purpose: "To voluntarily assist in relief of every kind and nature to those persons suffering from or exposed to alcohol or drugs in any degree, but primarily to musicians whose health or work is affected by alcohol or drugs" [30]. As of 8 August 1958, Mary Lou Williams had established a Bel Canto bank account. The total deposits to the account were $\$ 851.75$ by 28 August. She counted personal

5 In 1964, Williams revealed, "I put the worst cases in a room down the hall from my place I rent cheap from a neighbor. They stay a couple of weeks, and I talk to them and pray with them and help them get a job. But I can be very hard in my charity, and sometimes I tell them, 'You've got to be a man. Stand up and go downtown and get a job. No use lying around Harlem and feeling sorry for yourself.' Sometimes they come back in worse shape and ask for money, and sometimes they get on their feet. One boy I've been helping has a job at Gimbels, and he's doing just fine. I've also sent musicians to the Graymoor Monastery, near Garrison. Brother Mario [Hancock] there has been a lot of help to me." 
withdrawals from this account as loans to herself [31]. A 23 September 1958 bank deposit statement recorded that the Carnegie concert raised $\$ 2,922.75$, excluding sizable and minor donations totaling \$690.00 from jazz pianist Erroll Garner, Dave Brubeck (who could not attend but contributed \$10) [32], the noted jazz patroness Baronness Pannonica de Koenigswarter, Evie Ellington, and various judges and doctors whom Williams knew [33]. This total existed against a cost to Williams of $\$ 3,211.42$ for promoting and holding the concert, a sign for several of her invested friends that the foundation effort was a wash and should not proceed further ([28], p. 266). Williams intended to record a live album of the Carnegie Hall concert, with all proceeds benefiting her foundation. At her request, Bliss contacted the American Federation of Musicians for permission to record the volunteer musicians. However, Bliss received the response that "unless the performing musicians are paid recording wage scales," the union could not grant recording permission [34]. The unintended consequence of the musicians' charitable gesture, in foregoing payment for the concert, was that the profession's established labor practices prevented a potentially lucrative source of revenue (and avenue for broader publicity) for Williams's foundation. Nevertheless, Williams continued to navigate America's charitable landscape through publicity and fundraising letters [35].

Over the next few years, Williams sent fundraising letters as she devised new efforts to foster a sense of accountability between musicians and audiences. She organized rummage sales, offering "New Items from Saks Fifth Ave" including "children's clothes, shoes, dresses, books, house ware, dishes, antiques, men's clothes, original paintings, [and] lamps." She advertised the location of her rummage sales at 310 and 318 East 29th street in New York City, with weekly operational hours from "10[a.m.]-till" [36]. Advertisements for the rummage sales appear to be hand-drawn leaflets Williams likely distributed throughout her neighborhood. Despite the Carnegie concert's publicity, Williams was perhaps the only person truly convinced of her ability to establish the foundation. But the rummage sales served as a charitable concept that Williams maintained into the 1960s. Successful folks, musicians and otherwise, enjoyed an excess of material goods with which they could easily part. And even though all of these items were perishable in the long run, wealthier individuals had the means to buy sturdier, more durable goods that would be of great use, even through second-hand ownership. Williams and her successful friends donated their own luxury clothes, household items, and antiques in the ongoing effort to raise money for the Bel Canto Foundation. The rummage sale fostered the (re)circulation of material goods-within a local community, between two financially disparate socioeconomic classes, and for cheaper than original costs. This stood as an alternative to the conventional circulation of economic resources between these two classes, such as money dispensed through an hourly wage employment system. For her ultimate goal of benefiting jazz musicians on the social margins, Williams came to rely on a charitable commercial practice that linked the most marginalized of New York City's working class with its successful elites whose friendship, favor, and admiration she had earned over several years.

In 1959, Williams chose 308 East 29th Street as the location of a thrift shop to continue her practice of selling donated goods from musicians, socialites, and others, to fundraise for her foundation. In the long effort to realize her dream-to support musicians by holding others accountable for their care, Williams encountered the reality that in American society, the institutionalization of care required its own measures of accountability with which Williams had to become familiar. There were three related aspects of Williams's accountability: her personal bookkeeping, the maintenance of federal and state licenses to operate as a tax-free charity in the city, and establishing and maintaining her professional trustworthiness to (re)negotiate contracts and terms with her creditors. Official legal forms, bureaucratic liaisons, and constant personal correspondences served as the modes to institutionalize trust and credibility through accountability and transparency. To maintain her thrift shop in its more unprofitable moments, Williams also became responsible for drafting requests to revise payment terms and explaining insufficient funds for overdue bills, justifying her store's viability in order to renew licenses. Additionally, alongside continued appeals for funds and advertisements, she was responsible for diligent accounting of daily expenses. 
On Williams's individual part, her detailed expense books recorded the donations, sales, and personal finances she put into the thrift shop. Regular expenses in 1959 and 1960 included travel (train cost, cab and bus fare, tolls, parking tickets), transportation of materials (shipping, car rental), meals (for herself, relatives, and others), repairs (for the shop, the shop's car), shop maintenance (hardware, personal care products, cleaning supplies, office furniture and supplies), care for donated clothes (hangers, dry-cleaning), publicity (stamps, paint, posters, cardboard, printing), the shop's bills (telephone and gas), rental payments for the shop, and Williams's personal loans to the shop, for which she also recorded the shop's repayments to her. However, these expense books were also essential for holding her accountable about her own daily expenses, serving at times to remind her of the degree to which her time and income went toward personal errands and spending. Williams consistently recorded payments for her sister, Grace Mickles (who struggled with alcoholism), and for Grace's children [37]. Other expenses included her performance trips to other cities, the one-time services of an accountant, and the annual cost of a post office box. Total receipts for the shop, from 1 September through 31 December 1960 amounted to $\$ 1,035.32$. Against $\$ 357.38$ in expenses for that quarter, the total gain amounted to $\$ 677.94$ [38].

Naturally, accounting was central to participating in any institutionalized system of accountability. For the year ending 31 May 1960, Williams filed the New York State Department of Social Welfare's Annual Report for Charitable Organizations, declaring an income of $\$ 3,260.63$ ( $\$ 727.30$ from the rummage sale and $\$ 2,533.33$ in donations) and $\$ 1,952.50$ in expenses (\$973.74 for the rummage sale, and $\$ 978.76$, possibly related to fundraising donations), for a total net income of $\$ 1,308.13$ (although because of a miscalculation, she reported $\$ 100$ less than the actual total) [39]. Williams filed a financial report on 15 February 1961, a required submission to New York's Department of Welfare, Division of Public Solicitation. She declared $\$ 3,322.19$ in receipts $(\$ 1,531.77$ from the thrift shop sales and $\$ 1,790.42$ in donor contributions) and $\$ 1,599.64$ in total expenses, for a net income of $\$ 1,722.55$ (although Williams again mistakenly calculated the total as $\$ 10$ less than the actual amount). On the reverse page of the form, she indicated that the foundation's bank account contained $\$ 1,806.20$ for the purpose of "helping needy and deserving musicians." She also needed to explain two other expenses she titled "Loan repaid to M. L. Williams" and "Aid $\$ 62.38$ " in writing on the reverse page:

Aid: Check in the amount of 47.38 was given to Diane Coles to pay back room rent and to rehabilitate herself.

Aid: George Gordon, Musician, had heart attack on job. Took care of him by letting him watch thrift shop. Gave George Gordon 1 check for $\$ 10.00$ and 1 for $\$ 5.00$.

$\$ 100.00$ of $\$ 165.00$ loan made to fund by Mary Lou Williams. [40]

With this financial form and others, there were obvious descriptive limitations on what Williams could classify as her "care" for particular musicians, given her professional traveling schedule and other financial obligations in addition to managing the shop. Fifteen dollars for George Gordon was certainly not enough to cover his healthcare costs, but perhaps the relatively insubstantial amount obscures the degree of Williams's actual involvement when she "took care of him" in her shop-constant communication with Gordon over his period of recuperation, errands she may have run for him, recruiting others to check in on his progress, preparing meals for him, and even regular conversations with him about life, music, and future goals beyond his immediate illness. The checks may have even represented the official amount that she provided Gordon once he was well enough to leave the shop, concealing Williams's true religious labor-her investment of time and finances—-to ensure his recovery. Such matters of personal care are not as easy to quantify on federal forms, particularly when time was constantly a precious and limited resource for the busy Williams. Additionally, the George Gordon Singers performed for one of Williams's albums of religious jazz in 1964, so her personal and financial relationship with this musician extended well beyond what one individual form could capture.

In the 1960s, several musicians appeared in Williams's checkbooks as the recipients of payments for performances with her (in addition to personal loans): bassist George Tucker (1927-1965), who 
performed for Williams's trio; Andrew Cyrille (b. 1939), eventually an avant-garde drummer for jazz pianist Cecil Taylor, whose musical style represented a comical foe for Williams in her normative articulation of jazz as music ([28], pp. 259-62); drummer Berisford "Shep" Shepherd (b. 1917); drummer, arranger, and singer James "Osie" Johnson (1923-1966); double bassist and photographer Milton John "Milt" Hinton (1910-2000); and drummer Percy Brice (b. 1923) [41]. These musicians likely had stable enough employment to maintain bank accounts, whereas the thrift shop employees and struggling musicians Williams encountered most likely received "out-of-pocket" compensation or charity, respectively. In her 1965 income tax files, Williams indicated a total of \$227.76 in personal payments to several African American musicians: bassist Eustis Guillemet (b. 1934), drummer Granville William "Mickey" Roker (b. 1932), bassist Melbourne R. "Bob" Cranshaw (b. 1932), and a donation to pianist and composer Tadley Ewing Peake "Tadd" Dameron (1917-1965) [42]. It is plausible that Williams enlisted these musicians, and others, as her sidemen for various concert performances in order to afford them steady income and to allow them to continue exercising their musical gifts. But Williams also maintained lasting correspondences with some musicians, who shared with her their progress in (and frustrations with) the music industry, the details of their daily prayer habits, and their reflections on social unrest [43].

The irony of Williams never succeeding in raising the profile (and resources) of this foundation was that the constant care for her immediate family diverted her income, which she could have otherwise put towards the Bel Canto mission. As reflected in her checkbook, Williams's sister, Grace Mickles, and her children were the perpetual recipients of funds for essentials like food, overdue rent, clothing, and bus fare. Williams even paid Mickles's life insurance policy. Beyond the care of relatives, included in Williams's regular expenses were items essential to her embrace of Catholicism: she wrote checks regularly to Our Lady of Lourdes church for $\$ 20$ worth of prayer candles, $\$ 4$ for a Catholic pamphlet, $\$ 5$ for prayers from the Mother Mary Missions, \$30 for the Franciscan Missionary, a \$25 donation to the poor, and a $\$ 400$ donation to the Catholic Youth Organization. She recorded her donations to other congregations, like the Holy Rosary Church, St. Leo's Church, St. Mary's Catholic Church, and St. Patrick's Church. In addition to substantial (but infrequent) personal expenses, like $\$ 300$ gowns for her concerts, $\$ 124$ to cover recording session costs, $\$ 75$ expenses for hair care, the circulation of Williams's personal income for charitable and business purposes siphoned off potential resources for the foundation [41]. Sizable deposits of her own money into the thrift shop's account-such as personal checks totaling $\$ 864, \$ 2,000$ in concert revenues, her regular salary of $\$ 512.71$ for performing at the Hickory House nightclub in New York city, and a bank loan for \$2,000, all in 1965-never became enough to offset the store's preexisting rental debt, overdue utility bills, and her perpetual aid to others [44]. These expenses accompanied Williams's support for her mother, by this point ailing from cancer. In part, Williams's immediate charitable generosity and substantial family obligations counteracted the long-term religious mission she envisioned for a specific musical population.

\section{Conclusions: Alternative Modes of Religious Community and Discourse, Novel Practices of Devotional Labor and Leadership}

Duke Ellington sympathized with any effort to affirm God and to affirm believing in God. While on the road in the mid-1960s, in preparation for his Sacred Concerts, he used hotel stationery to make notes to himself concerning potential lyrics for his sacred music. In this process, he was transcribing his efforts to verbalize what it meant to express belief in God. A reflection at the Detroit Hilton hotel became a driving assertion of his sacred concerts: "Every Man Prays in His Own Language \& there is No Language GOD Does Not Understand." With the opposite side of the paper, Ellington explained that music was "My Language," that it "Got Me into Church," and that it was "Possibly My Most Eligible Form of Semantics-if I am to Speak to GOD" [45]. The constantly touring Ellington made sense of God on the road without a regular church home, theologizing as he read the Christian Bible and engaged mostly liberal religious literature [46]. When he finally attended houses of worship, it was without adhering to their specific doctrinal commitments-it was as a celebrated musician, 
similar to an honored guest preacher, but bearing a primarily musical and nondenominational message. In these moments, the famous composer could bypass lay status within any denomination and enjoy a relatively exalted status in white religious spaces (and in the black religious spaces where ministers and congregants respected his jazz career) as a professional African American artist who enjoyed more than forty years of career success.

Ellington was a prominent African American race representative and served such a role in white religious spaces, although the religious literature he enjoyed did not emerge from African American Christian denominations or thinkers. The home of Ellington's Sacred Concert music was not the mainline African American Protestantism of Washington, D.C. in which his parents raised him. Rather, Ellington engaged an explicitly ecumenical religious project that brought him into the world of white mainline liberal Protestantism in the United States and of Western Europe. Additionally, the theological reflections that Ellington produced with his sacred musical compositions represented his responses to the discourses and concerns of liberal Christianity, particularly in his manner of wrestling with appropriate language to address and characterize the nature of God, and with the noteworthy absence of Jesus Christ and the Holy Spirit from the language of a composer moving primarily throughout mainline Christian religious spaces.

Moreover, while Ellington bore implicitly the task of representing African American Christianity in his new music, his primary familiarity with African American religious life was relegated to his childhood, where he spent Sundays between his father's African Methodist Episcopal Zion church and his mother's National Baptist Convention, USA church. Engagement with the evolving expressions and theologies of Afro-Protestantism in the first half of the twentieth century was absent in Ellington's adulthood, and he gravitated more toward white mainline Protestant leaders, thinkers, and religious spaces. His sister, Ruth, a significant champion of Ellington's religious legacy, a congregant at St. Peter's Lutheran Church in Manhattan, and his family member most responsible for creating his archive, was similarly situated between white mainline and evangelical religious worlds [47]. Gospel developed as an African American music form and industry in the years between Ellington's religious youth and his Sacred Concerts in the mid-1960s, and its popularity spread throughout African American Christianity (from Holiness-Pentecostal churches to the Baptist and Methodist mainline). Consequently, a significant temporal and theological gulf existed between Ellington's religious life and that of many African American Christians, despite Ellington's de facto identity as an African American racial and religious representative to predominantly white mainline Protestant audiences. In this light, the greater posthumous popularity of Ellington's sacred music in white American mainline and European Protestant churches is not an ironic outcome, and these are the congregations that continue to perform his compositions annually.

Undeniably, Mary Lou Williams's Bel Canto Thrift Shop failed as a sustainable business. However, the overwhelmingly negative assessments of her work on this project from the late 1950s through the 1960s deals insufficiently with the worth of her daily labor to run her shop, to manage her finances, and to aspire to realize a support system for musicians in need and, thereby, forge a new sense of community between jazz artists and broader societies. Biographer Dahl's sources for analysis of the foundation effort and management of the thrift shop did not include the musicians who were recipients of Williams's charity. The primary voices are those who financed Williams's initial mission efforts (ultimately at a loss) and those who sought to refocus her attention on composing and performing new jazz music. Williams, ever the meticulous record-keeper, maintained many of the documents related to her foundation efforts that reveal moments of promise, setback, progress, and failure. These documents also provide a record of several musicians who experienced Williams's charity, regardless of the foundation's ultimate fate.

To probe the worth of establishing and maintaining the Bel Canto Foundation for Williams, the professional jazz musician, convert, and African American woman, is to explore the persistent diligence of an entrepreneurial (and Catholic) newcomer whose primary musical profession likely prevented established social service organizations, prospective financiers, and Catholic authorities from taking 
her efforts seriously enough to robustly support her mission. This effort to establish the Bel Canto Foundation represented tensions for Williams the musician. There was the fundamental tension in managing her professional output (traveling to perform and produce new music) versus managing her Bel Canto Foundation's daily affairs (the local operation of her thrift shop and maintaining correspondences with potential donors). However, there was another tension for Williams the successful African American jazz artist. While she was a newcomer to the Roman Catholic faith, having been baptized and confirmed on 9 May 1957 following several years of religious exploration, she was anything but a novice in her musical profession. Williams was an adult who charted a path to prominence within one jazz community, confident in her ability to manage a substantial project like this foundation because she had secured revenue for herself through the ongoing retrieval and management of her composition copyrights. Consequently, she strived to become more than a regular parishioner in her new Catholic community. She attracted the friendship of many Catholic priests and enjoyed retreats with religious Catholic women, like the Cenacle Sisters Convent in Lancaster, Massachusetts [48]. These were relationships where Williams sought conversation and prayer partners about matters mundane, grave, and lighthearted; yet she also actively sought the Catholic hierarchy's legitimization of the moral work she began prior to her formal conversion, partially through the Church's financial investment in her entrepreneurial efforts. The Catholic authorities she befriended, however, were fans of Williams the prominent jazz artist, not necessarily Williams the charitable organization executive. They encouraged her to put her full energies into developing her music (in particular, developing her concept of "sacred jazz") rather than treading into unfamiliar professional territory.

By 1966, Mary Lou Williams was no longer involved in the daily management of her Bel Canto Thrift Shop. Williams strived to provide musicians their own contemplative, creative space through her daily labor to realize her foundation by managing her thrift shop and seeking various fundraising strategies. And some of those musicians made daily journeys into her Catholic community through mass attendance, priestly consultations, and correspondences with Williams herself. For Williams, the labor of her thrift shop activity served an interstitial purpose- - between a sense of divine calling without a specific religious home, and her explicitly Catholic practices and production of sacred jazz.

Duke Ellington embraced the authority to speak about God that listening audiences afforded him, and he sought to do so publicly so that Protestants, Jews, and Catholics would accept his musical messages. However, Ellington's private reflections in hotels reveal that the composer never used specifically Protestant, Jewish, or Catholic language to speak of his God. For many other jazz musicians in need, Mary Lou Williams served as the financial and communal intermediary between personal (and emotional) destitution and professional stability. She sought to create a new social institution with a new understanding of her divine calling. However, Williams's pursuit of reviving jazz creativity to forge "good" jazz music did not require making new Catholics. For scholars of American religion, engaging the archives of these two African American jazz musicians reveals complex individual religious identities, expressions, and practices that allow us to view women and men attempting to define precisely their religious roles and affiliations as well as articulating belief in their personal and professional lives.

Acknowledgments: I am grateful to Judith Weisenfeld, Wallace Best, Jessica Delgado, Clifton Granby, Kijan Bloomfield, Irene Elizabeth Stroud, and the Religion in the Americas and Religion and Culture workshops at Princeton University for their feedback on earlier papers that became this publication. Additionally, I am grateful to Tad Hershorn and Joe Peterson of the Institute of Jazz Studies, and to Wendy Shay and Joe Hursey of the National Museum of American History Archives Center at the Smithsonian, for their research assistance in locating archival materials for this publication.

Conflicts of Interest: The author declares no conflict of interest. 


\section{References and Notes}

1. While concerns about the cultural and moral worth of jazz lingered for black Christian clergy over the next few decades, the music came to represent an idealized set of democratic and expressive possibilities in the Cold War era and functioned as a reflection on the progressive strides of civil rights activism. This evolution in perception accompanied innovations and developments in music and performance, where jazz enjoyed a smaller audience no longer interested in big band dance music and more invested in the music as a listening, intellectual artistic experience that small instrumental combos created. Fans and professional critics signified jazz musicians as artistic virtuosos, America's international cultural ambassadors, and representatives of an elite African American culture capable of capturing, through music, the sounds, moods, and political desires of a people. For more, see Penny M. Von Eschen. Satchmo Blows Up the World: Jazz Ambassadors Play the Cold War. Cambridge: Harvard University Press, 2004.

2. For jazz scholar Holly Farrington, racial representation is evident in the jazz profession because of the production of more than forty jazz autobiographies between 1936 and 1996. Duke Ellington's 1973 autobiography, Music Is My Mistress, revealed that the musician was "always on stage" when performing, and "his racial identity forced him to become a representative, linking public perception of African Americans irretrievably to the individual achievement of celebrities and artists such as himself." See Holly E. Farrington. "Narrating the Jazz Life: Three Approaches to Jazz Autobiography." Popular Music and Society 29 (2006): 375-86. [CrossRef]

3. In the history of civil rights legal activism, according to historian Kenneth Mack, race representation refers to "those who claimed to speak for, stand in for, and advocate for the interests of the larger group." Since the nineteenth century, for African Americans to call for a "representative colored man" or "representative Negro" has involved a tension between an atypical member of the race in terms of her or his accomplishments and an "authentic" member of the race who was "as much like the masses of black people as possible." The representative colored men, "...the lucky few who had attained enough education and training to become doctors, dentists, schoolteachers, ministers, and lawyers," were to serve as the best cases for full and equal African American citizenship. See Kenneth W. Mack. Representing the Race: The Creation of the Civil Rights Lawyer. Cambridge: Harvard University Press, 2012, pp. 4, 5, 20. Popular black jazz professionals became de facto race representatives because of their coverage in the black and white press, due to their inter/national travel and publicity, and because of the emergence of music criticism.

4. Edward Kennedy Ellington, and Mercer Ellington. Music Is My Mistress. Garden City: Doubleday, 1973.

5. For further analysis of Ellington's racial and religious themes in his popular compositions, see Vaughn Booker. "'An Authentic Record of My Race': Exploring the Popular Narratives of African American Religion in the Music of Duke Ellington." Religion and American Culture: A Journal of Interpretation 25 (2015): 1-36. [CrossRef]

6. “Rough Copy," p. 2, Series 5: Performances and Programs, 1963-1989, Box 5, Folder 4 (Duke Ellington's Festival of Religion and the Arts, 1966), Ruth Ellington Collection, Archives Center, National Museum of American History.

7. “The Baltimore Hilton, Baltimore, MD," Series 5: Personal Correspondence and Notes, 1941-1974, Box 6, Folder 1 (Notes, undated), Duke Ellington Collection, Archives Center, National Museum of American History.

8. “Obituary-Raymond Walter Johnson." The Seattle Times, 2010. Available online: http:/ /www.legacy.com/ obituaries / seattletimes/obituary.aspx?pid=146007696 (accessed on 10 October 2014).

9. "Destined For Greatness," (Seattle, WA: Life Messengers, date unknown), Series 14: Religious Material, 1928-1974, Box 2, Folder 2, Duke Ellington Collection, Archives Center, National Museum of American History.

10. “Jacksonville Hilton, Jacksonville, FL," Series 5: Personal Correspondence and Notes, 1941-1974, Box 6, Folder 1 (Notes, undated), Duke Ellington Collection, Archives Center, National Museum of American History.

11. “Downtowner/Rowntowner Motor Inns, location unknown," Series 5: Personal Correspondence and Notes, 1941-1974, Box 6, Folder 1 (Notes, undated), Duke Ellington Collection, Archives Center, National Museum of American History. 
12. "Hotel Washington, Washington, DC," Series 5: Personal Correspondence and Notes, 1941-1974, Box 6, Folder 1 (Notes, undated), Duke Ellington Collection, Archives Center, National Museum of American History.

13. Duke Ellington with Erich Kunzel and the Cincinnati Symphony Orchestra. "Poetic Commentary 'A'," Orchestral Works, (c) 1989, 1970 by MCA Records, Inc., MCAD-42318, Compact disc.

14. "Ramada Inn Roadside Hotel, San Antonio, TX," Series 5: Personal Correspondence and Notes, 1941-1974, Box 6, Folder 1 (Notes, undated), Duke Ellington Collection, Archives Center, National Museum of American History.

15. "Ramada Inn Roadside Hotel, Greensboro, NC," and “The Baltimore Hilton, Baltimore, M.D.," Series 5: Personal Correspondence and Notes, 1941-1974, Box 6, Folder 1 (Notes, undated), Duke Ellington Collection, Archives Center, National Museum of American History.

16. "Ilikai Wakiki, Honolulu, HI," Series 5: Personal Correspondence and Notes, 1941-1974, Box 6, Folder 1 (Notes, undated), Duke Ellington Collection, Archives Center, National Museum of American History.

17. Harvey G. Cohen. Duke Ellington's America. Chicago: University of Chicago Press, 2010.

18. Edward Kennedy Ellington. Duke Ellington's My People. (C) 1992, 1963 by Legacy Recordings, AK-52759, Compact disc. The line "Snatched Jonah, yes He did, from the belly of the whale" contains the masculine pronoun to refer to God. However, Ellington's manuscript lyrics for this song do not include "yes He did," appearing instead as "Snatched Jona/From the belly of the whale." This indicates McPhail's original improvisation of the line. Nevertheless, this inclusion of exclamatory speech acknowledges the importance of this way of testifying about God in African American Protestantism. This composition existed prior to

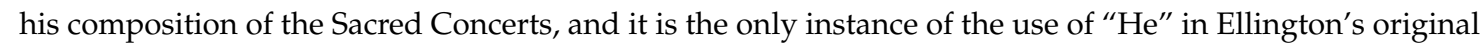
Sacred Concert lyrics. See “My People by Duke Ellington-Ain't But The One," p. 5, Series 5: Handwritten Notes, Etc., Queenie Pie, Box 8, Folder 12, Duke Ellington Collection, Archives Center, National Museum of American History.

19. Edward Kennedy Ellington. "Supreme Being," Second Sacred Concert, (c) 1990, 1968 by Prestige Records, PCD 24045-2, Compact disc.

20. Wilbert Hill writes that "Tell Me It's the Truth" is an example of Ellington incorporating characteristics of 1950s and 1960s gospel music in his First Sacred Concert, namely, "...use of the tambourine, triple meter, a simple harmonic progression, call and response, and idiomatic orchestration of the gospel style accompaniment part supporting the melody sung by a contralto." See Wilbert Weldon Hill. "The Sacred Concerts of Edward Kennedy 'Duke' Ellington." Ph.D. Dissertation, The Catholic University of America, 1995. p. 76.

21. “The Shamrock Hilton, Houston, TX," Series 5: Personal Correspondence and Notes, 1941-1974, Box 6, Folder 1 (Notes, undated), Duke Ellington Collection, Archives Center, National Museum of American History.

22. "Jazz Goes to Fifth Avenue Church." Christianity Today 10 (1966): 42.

23. "A Statement from Duke Ellington," Series 5: Performances and Programs, 1963-1989, Box 5, Folder 4 (Duke Ellington's Festival of Religion and the Arts, 1966), Ruth Ellington Collection, Archives Center, National Museum of American History.

24. "Has the Black American Musician Lost His Creativeness and Heritage in Jazz?" p. 1, 4, Series 5: Personal Papers, ca. 1970-1971, Box 2, Folder 25, Mary Lou Williams Collection, Institute of Jazz Studies, Rutgers University.

25. Lowell D. Holmes, and John W. Thomson. Jazz Greats: Getting Better with Age. New York: Holmes \& Meier Publishers, Inc., 1986.

26. Smithsonian Institution Interviews with Jazz Musicians: Williams, Mary Lou, Jazz Oral History Project 117.5.5, Transcript, Institute of Jazz Studies, Rutgers University. After she stopped performing at Café Society, Williams regarded her apartment as "...a headquarters for young musicians." She stated, "I'd even leave the door open for them if I was out. Tadd Dameron would come to write, when he was out of inspiration, and Monk did several of his pieces there. Bud Powell's brother, Richie, who also played piano, learned how to improvise at my house. And everybody came or called for advice. Charlie Parker would ask what did I think about him putting a group with strings together, or Miles Davis would ask about his group with the tuba - the one that had John Lewis and Gerry Mulligan and Max Roach and J. J. Johnson in it. It was still like the thirties-musicians helped each other, and didn't just think of themselves." 
27. Whitney Balliett. "Profiles: Out Here Again." The New Yorker, 2 May 1964.

28. Tammy L. Kernodle. Soul on Soul: The Life and Music of Mary Lou Williams. Boston: Northeastern University Press, 2004.

29. Linda Dahl. Morning Glory: A Biography of Mary Lou Williams. New York: Pantheon Books, 1999.

30. "Certificate of Incorporation of Bel Canto Foundation, Inc., Pursuant to the Membership Corporation Law," p. 1, Series 4: Business Papers, Subseries 4L: Bel Canto, ca. 1950-1971, 1977, undated, Box 67, Folder “Bel Canto, Certificate of Incorporation, New York, New York, 1958," Mary Lou Williams Collection, Institute of Jazz Studies, Rutgers University.

31. "Bel Canto Account-Disbursement and Receipts," Series 4: Business Papers, Subseries 4L: Bel Canto, ca. 1950-1971, 1977, undated, Box 47, Folder 6 (Benefit Activities [Concert, Rummage Sale, etc.]), Mary Lou Williams Collection, Institute of Jazz Studies, Rutgers University.

32. “Letter to Mary Lou Williams from Dave Brubeck, September 23, 1958," Series 4: Business Papers, Subseries 4L: Bel Canto, ca. 1950-1971, 1977, undated, Box 47, Folder 6 (Benefit Activities [Concert, Rummage Sale, etc.]), Mary Lou Williams Collection, Institute of Jazz Studies, Rutgers University.

33. "Bell Telephone Company—Deposits," Series 4: Business Papers, Subseries 4L: Bel Canto, ca. 1950-1971, 1977, undated, Box 47, Folder 6 (Benefit Activities [Concert, Rummage Sale, etc.]), Mary Lou Williams Collection, Institute of Jazz Studies, Rutgers University.

34. "Letter from Herbert J. Bliss to Mr. Henry Zaccardi, American Federation of Musicians, September 10, 1958," and "Letter from Henry Zaccardi to Herbert J. Bliss, September 16, 1958," Series 4: Business Correspondence, Subseries 4I: Legal Affairs, 1941-1980, undated, Box 41, Folder 2 (Bliss, Herbert J., 1958), Mary Lou Williams Collection, Institute of Jazz Studies, Rutgers University.

35. “Bell Telephone Company—'Loot to Boot' Paid Out," Series 4: Business Papers, Subseries 4L: Bel Canto, ca. 1950-1971, 1977, undated, Box 47, Folder 6 (Benefit Activities [Concert, Rummage Sale, etc.]), Mary Lou Williams Collection, Institute of Jazz Studies, Rutgers University. Williams wrote checks for advertisements in the New York Times, the New York Amsterdam News, and for poster and banner advertisements. The Carnegie Hall booking cost $\$ 1,740.38$, while other miscellaneous costs like parking tickets, supplies, and car rental added to her total. Additionally, Williams' bank statement lists the total cost as $\$ 3,210.42, \$ 1$ lower than the accurate total.

36. “Rummage Sale-at 318 East 29 St" and "Rummage Sale! 310 East 29th Street," Series 4: Business Papers, Subseries 4L: Bel Canto, ca. 1950-1971, 1977, undated, Box 47, Folder 6 (Benefit Activities [Concert, Rummage Sale, etc.]), Mary Lou Williams Collection, Institute of Jazz Studies, Rutgers University.

37. “Bel Canto Expenses," Series 4: Business Papers, Subseries 4L: Bel Canto, ca. 1950-1971, 1977, undated, Box 47, Folder 8 (Bound Notebook, New York, New York, 1959-1960), Mary Lou Williams Collection, Institute of Jazz Studies, Rutgers University.

38. “Bel Canto Foundation Expenses...1960,” pp. 1, 2, and “Summary," Series 4: Business Papers, Subseries 4L: Bel Canto, ca. 1950-1971, 1977, undated, Box 48, Folder 5-8 (Financial Records-Expenditures, Inventory, Transactions, New York, 1958-1971, undated), Mary Lou Williams Collection, Institute of Jazz Studies, Rutgers University.

39. "Form CR-131, 'Annual Report-Charitable Organizations,'” Series 4: Business Papers, Subseries 4L: Bel Canto, ca. 1950-1971, 1977, undated, Box 49, Folder 4 (Licenses, Leases, Insurance, State and Local Documents, 1959-1961), Mary Lou Williams Collection, Institute of Jazz Studies, Rutgers University.

40. "Form M-537g, 'Financial Report'," Series 4: Business Papers, Subseries 4L: Bel Canto, ca. 1950-1971, 1977, undated, Box 48, Folder 5-8 (Financial Records-Expenditures, Inventory, Transactions, New York, 1958-1971, undated), Mary Lou Williams Collection, Institute of Jazz Studies, Rutgers University.

41. “Checkbooks and Balance Registers, 1962-1964," Series 4: Business Papers, Subseries 4M: Banking, Box 50, Mary Lou Williams Collection, Institute of Jazz Studies, Rutgers University.

42. "Mary Lou Williams (Income Tax)," p. 1, Series 4: Business Papers, Box 62, Folder "Taxes-Federal Income Taxes, 1965," Mary Lou Williams Collection, Institute of Jazz Studies, Rutgers University.

43. Between 1965 and 1966, Eustis Guillemet updated Williams on his decision to leave New York City, in addition to his occasional requests for financial support for music equipment and rent. While staying at a YMCA in Atlantic City, NJ, Guillemet informed Williams of the changing social climate: “...[T]here might be more marches and sit ins this summer. The whites live on one side[,] the colored on the other. Most of the youngsters are participating in either marches or sit ins. So say some extra prayers that God will show His 
justice and graces in bettering conditions of both people if it be His Holy Will and salvation of the Souls involved." On his regular Catholic practices, Guillemet conveyed to Williams his dedication in moments of personal frustration: "Good talking to you and very good reading from ya. I was uptight at the time and at a very low point. Not that I didn't know what to do, I just couldn't get together but I did as I talked to a priest and he told [me] that sometimes God permits stress and strain to show us how weak we are and upon asking His Graces, He lets us know that we are still dependent on Him...One day I got a good look at the people I've been around and it frightened me. I hope I wasn't looking at myself. If I was I have a long way to go and a lot of work to do. Anyway I went to New York and sat with the Blessed Sacrament and a day later I got myself together. I guess I was away too long. The Sacrament isn't exposed too often here and there aren't too many Catholics, active that is. But like you said[,] pray and keep your mind on the music. That I will do with all determination because every time I look the other way I start getting in trouble." See "Letter from Eustis Guillemet to Mary Lou Williams, February 5, 1965," "Letter from Eustis Guillemet to Mary Lou Williams, May 30, 1966," and "Letter from Eustis Guillemet to Mary Lou Williams, 22 June 1966," Series 3: Personal Correspondence, Subseries 3B: Correspondence with Friends, ca. 1925-1952, 1958-1981, Box 8, Folder 11 (Eustis Guillemet, 1965-1973, undated), Mary Lou Williams Collection, Institute of Jazz Studies, Rutgers University.

44. “Mary Lou Williams (Income Tax)," p. 3, Series 4: Business Papers, Box 62: Folder Taxes-Federal Income Taxes, 1965, Mary Lou Williams Collection, Institute of Jazz Studies, Rutgers University.

45. "The Detroit Hilton, Detroit, MI," Series 5: Personal Correspondence and Notes, 1941-1974, Box 6, Folder 1 (Notes, undated), Duke Ellington Collection, Archives Center, National Museum of American History.

46. Ellington received much of his religious literature as gifts from clerical fans. His collection of religious literature reveals that a profession of religious commitment in twentieth-century America does not seal the individual off from the reality of competing religious commitments, which may even appear as the well-intentioned proselytizing of others who admire a popular jazz musician and wished for him to join their particular fellowship. Nevertheless, Ellington received these gifts as clergy encouraging him to create sacred music "not as a matter of career, but in response to a growing understanding of my own vocation." See "A Statement from Duke Ellington," Series 5: Performances and Programs, 1963-1989, Box 5, Folder 4 (Duke Ellington's Festival of Religion and the Arts, 1966), Ruth Ellington Collection, Archives Center, National Museum of American History.

47. Douglas Martin. "Ruth Ellington Boatwright, 88, the Sister of Duke Ellington." The New York Times, 11 March 2004. Available online: http://www.nytimes.com/2004/03/11/arts/ruth-ellington-boatwright88-the-sister-of-duke-ellington.html (accessed on 31 October 2014).

48. See Series 3: Personal Correspondence, Subseries 3D: Correspondence with Religious, Box 20, Folder 14 (Sister Martha Morris: Correspondence, 1967), Mary Lou Williams Collection, Institute of Jazz Studies, Rutgers University.

(C) 2016 by the author; licensee MDPI, Basel, Switzerland. This article is an open access article distributed under the terms and conditions of the Creative Commons Attribution (CC-BY) license (http://creativecommons.org/licenses/by/4.0/). 